\title{
Migration Discrepancies
}

\section{ARTHUR WARD, Swift Current}

The urge of birds to come and go in many instances takes on a pattern, sometimes influenced by the weather so it would seem. However there are many factors which are revealed by bird banders. There is the tendency of some species to maintain throughout the years a constant route then abandon it for perhaps a decade.

It is evidently not the lack of food that impel some birds to return to the Austral Zones. In our experience the Clay-colored Sparrow is notable in this respect during those years when there is an absence of water in the innumerable sloughs across the country. These birds, with a preponderance if immature, concentrated in our bird sanctuary during August in so great numbers that many had to be freed from the traps without bands. There were no repeats in the traps which emphasized. their eagerness to keep going south.

Of the 16 lists compiled by members in the last issue, it was surprising to see that not one contained the name of the Fox Sparrow among the migrating birds arriving. It would have been interesting to note that this large handsome bird had been included in my list if I had not forgotten to send it in. There were seven of them, very touchy at the slightest sound, but they would come back to scratch vigorously with both feet at the edge of the feed, so unlike the Red-eyed Towhee that scratches like a hen. These two latter species have been added to the other four outstanding "seldom seen birds" that I have banded, namely, the Varied Thrush, Townsends Solitaire, Yellowbreasted Chat and Dickcissel.

I also banded a Lark Sparrow, June 9,1942 . This bird, considered plentiful in some areas, was not seen again until this summer while we were visiting at the beautiful treed ground of I. W. Studer, an area of some 30 acres situated 32 miles south of Swift Current. There too, we heard the call of the Black-billed Cuckoo, which Mr. Studel described as new to him. I banded two of these birds in 1926. They were frequent visitors to our grove at that time, but afterwards were not seen or heard again for 14 years.

The absence of some species from certain districts where they once were recorded as frequent and plentiful visitors, would be well worthy of o u r attention in ascertaining whether the numbers were being maintained in other zones.

\section{Some Fall Migrating Dates}

P. Laurence Beckie, Bladworth, Sask. Eastern Kingbird, last seen - Sept 5. Brown Thrasher - Sept. 5.

American Pipets - Sept. 18

Burrowing Owls - Sept. 11

Pelicans - saw a flock of about 85 birds flying south, near Hanley, Sept. 17.

Flickers - Sept. 17, 18, 19.

Myrtle Warblers - first numerous flock - Sept. 19.

Junco - first fall date, Sept. 19.

White-crowned Sparrow — first fall date, Sept. 13.

Lapland Longspurs - first fall date - Sept. 18.

Coopers Hawk... Sept. 19.

\section{Jottings from Punnichy}

\author{
Madeline B. Runyan
}

During October we saw two birds, rare in this locality, namely, a Redbreasted Nuthatch, and a Canada Jay.

At first glance the tiny Nuthatch reminded one of a wren, but I soon realized that the wrens had long since migrated. The field glasses revealed a busy little mite running head first down the trunks of the elms with as great ease as he ran up - peering into every cranny in the search for insects or eggs.

The Canada Jay was brought to our attention by the Chickadees who were holding an indignation meeting around him.

The Blue Jay is also rare here. Five beauties were seen recently on the hill-side just out of Punnichy. 